\title{
Xanastur (Brachiopoda, Stringocephalacea) nomen novum pro Xana García- Alcalde, 1972 (non Xana Kurdjumov, 1917, Hymenoptera, Hexapoda)
}

\author{
Jenaro L. GARCÍA-ALCALDE
}

Department of Geology, University of Oviedo, c/ Jesús Arias de Velasco, s/n., 33005 Oviedo, jalcalde@uniovi.es

García-Alcalde, J.L. 2021. Xanastur (Brachiopoda, Stringocephalacea) nomen novum pro Xana García-Alcalde, 1972 (non Xana Kurdjumov, 1917, Hymenoptera, Hexapoda). Spanish Journal of Palaeontology, 36 (1), 77-78.

Manuscript received 30 October 2020

https://doi.org/10.7203/sjp.36.1.20308

Manuscript accepted 16 December 2020

(C) The Authors (2021)

García-Alcalde (1972) proposed the new genus Xana (type species Xana bubo García-Alcalde, 1972) for a terebratulid brachiopod included in the superfamily Stringocephalacea from the Lower Devonian of the Cantabrian Mountains (Northwestern Spain). In an email message sent on April 3, 2018, the entomologist Dr. Eduardo I. Faundez, from the Patagonia Institute, Magallanes University, Chile, warned the author that Xana was a name previously used by Kurdjumov (1917) for a hymenopteran genus. Xana García-Alcalde, 1972 would be so a later homonym of Xana Kurdjumov, 1917. In accordance with articles 52.3, $52.4,53.2,60.3$ of the International Code of Zoological Nomenclature (ICZN) (2000), it is proposed here to replace the invalid name with the new name Xanastur. This name refers to the original substituted name (Xana, a legendary river and forest nymph) and to the typical region inhabited by the xanas (Asturias, Northwestern Spain). The type species would be Xanastur bubo (García-Alcalde, 1972).

Incidentally, Diaz Cosín et al. (1989) also proposed a new genus Xana, with the same García-Alcalde's derivatio nominis, for Xana omodeoi n. sp., an Asturian Annelida Oligochaeta. But when noticing that Xana was already used by Kurdjumov, Marchán et al. (2018) proposed to substitute the junior homonym for Xanina (meaning "small xana" a diminutive common in the Asturian region), with Xanina omodeoi (Díaz Cosín et al., 1989) as the type species.

The magic of the Asturian xanas spread more and more: insect, fossil, worms...

\section{ACKNOWLEDGEMENTS}

We deeply appreciate the kindness of Dr. Eduardo I. Faundez, who brought to our knowledge the taxonomic anomaly mentioned above.

\section{REFERENCES}

Díaz Cosín, D.J., Briones, M.J.I. \& Trigo, D. 1989. Descripción de una nueva especie de lombriz de tierra, Xana omodeoi (Hormogastridae, Oligochaeta) y sus implicaciones en la división de los Hormogastridae. Revue d'Écologie et Biologie du Sol, 26, 225-231.

García-Alcalde, J.L. 1972. Braquiópodos Devónicos de la Cordillera Cantábrica. 2) Género Xana García-Alcalde, n. gen. (Terebratulida, Stringocephalacea). Breviora Geologica Asturica, 16, 4-12.

International Code of Zoological Nomenclature (ICZN) 2000. Fourth Edition, International Union of Biological Sciences. Higher Council for Scientific Research, National Museum of Natural Sciences, I-XXIX + 156 pp.

Kurdjumov, N.V. 1917. New genus and species of Aphelininae. Zhurnal Prikladnoy Entomologii Kiev, 1, 80-81.

Marchán, D.F., Fernández, R., Sánchez, N., de Sosa, I., Díaz Cosín, D.J. \& Novo, M. 2018. Insights into the diversity of Hormogastridae (Annelida, Oligochaeta) with description of six new species. Zootaxa, 4496, 065-095; doi: 10.11646/zootaxa.4496.1.6. 
